\title{
Movimento dos Pequenos Agricultores (MPA), dieta contemporânea e politização da alimentação
}

\section{Small Farmers Movement (MPA), contemporary diet and politicization of food}

Jennifer Harumi Tanaka ${ }^{1}$

As transformações do sistema agroalimentar a partir de meados do século XX causaram grandes impactos na relação produção-consumo. Nesse contexto, "comer", "comida de verdade" e "alimentação saudável" tornaram-se termos que representam disputas de projetos ideológicos, sociais, econômicos e ambientais.

Nesse contexto, movimentos de consumidores e movimentos sociais que congregam pequenos produtores passaram a contestar e a contrapor-se aos modelos coorporativos globais atualmente dominantes no sistema agroalimentar, reivindicando as definições, os sentidos e os significados do que deveria ser a dieta contemporânea. Eles defendem, especialmente, a incorporação de valores sociais e culturais nas práticas de produção, comercialização e consumo de alimentos, indo de encontro a algumas das tendências da alimentação contemporânea, tais como: saudabilidade, sustentabilidade e valorização de origem.

Os efeitos desta discussão são nítidos na construção de pautas e propostas políticas do Movimento dos Pequenos Agricultores (MPA), por exemplo. Uma revisão histórica da trajetória do MPA aponta que sua atuação enquanto movimento social do campo se dá predominantemente no âmbito político ideológico. O foco principal de suas ações se circunscreve, sobretudo, em torno de atividades que visem à garantia das condições da reprodução social de camponeses. Contudo, nota-se, nos anos mais recentes, que outras pautas vêm ganhando centralidade para o movimento, o qual, como forma de resistência ao agronegócio e visando à construção de mercados, tem disputado e se posicionado sobre quais são os alimentos que devem compor a dieta contemporânea.

Frente a isso, a proposta do presente estudo é analisar tanto a trajetória histórica quanto as experiências mais atuais capitaneadas pelo MPA no estado do Rio de Janeiro, tendo como foco as discussões sobre a dieta contemporânea proposta e defendida por esse movimento social. A estratégia metodológica baseia-se em uma abordagem qualitativa de coleta e análise de dados, a partir de conteúdo de documentos e posicionamentos oficiais no âmbito nacional e estadual do movimento, aliado a uma entrevista semiestruturada com um membro da Coordenação Nacional do MPA e à observação participante durante algumas atividades realizadas pelo movimento na capital fluminense.

Avalia-se que o estudo das discussões sobre dieta contemporânea por movimentos sociais clássicos que defendem bandeiras tradicionais a partir de um ponto de vista histórico pode contribuir para ampliar o entendimento acadêmico do comer, da comida e da alimentação como espaços de ação política. Espera-se, dessa maneira, explorar outras concepções de dieta para além de seu caráter biológico, trazendo, nesse caso, reflexões que apontam para a redescoberta de seus 
elementos cívicos, os quais podem contribuir para o entendimento do comedor enquanto ator político e aliado de movimentos e causas sociais.

Palavras-chave: dieta contemporânea; alimentação saudável; movimentos sociais do campo; Movimento dos Pequenos Agricultores (MPA); relação produção-consumo.

Keywords: contemporary diet; healthy eating; social rural movements; Small Farmers Movement (MPA); production-consumption ratio.

1 Doutoranda em Ciências Sociais na Universidade Federal Rural do Rio de Janeiro. 